\title{
Clinical Radiological and Pathological considerations of Epiphysitis and Apophysitis
}

\author{
Lázaro Martín Martínez Estupiñan 1*, Leonardo Martínez Aparicio ${ }^{1}$, Lázaro Martínez Aparicio ${ }^{1}$, Sergio Morales Piñéiro ${ }^{1}$, Ernesto Ibañez \\ Zamora $^{1}$ \\ ${ }^{1}$ University General Hospital "Mártires Del 9 De Abril". Sagua la Grande. Villa Clara Cuba.
}

*Corresponding Author: Lázaro Martín Martínez Estupiñan, University of Beira Interior - CIDESD.

Received Date: October 22, 2021; Accepted Date: November 26, 2021; Published Date: December 09,2021

Citation: Martínez Estupiñan LM, Leonardo M. Aparicio., Lázaro M. Aparicio., Sergio M. Piñéiro., Ernesto I. Zamora (2021). Clinical

Radiological and Pathological considerations of Epiphysitis and Apophysitis. J. Clinical Orthopedics and Trauma Care, 3(1); DOI:10.31579/2694-

0248/016

Copyright: ( 2021 Lázaro Martín Martínez Estupiñan, This is an open access article distributed under the Creative Commons Attribution License, which permits unrestricted use, distribution, and reproduction in any medium, provided the original work is properly cited.

\begin{abstract}
A prospective longitudinal study of 157 patients between the ages of five and 16 years, high-performance athletes, who were treated with epiphyseal and / or apophyseal injuries due to chronic stress in our service, was carried out in the period between January 1, 2000 and December 31, 2020, at the Mártires del 9 de Abril University Hospital in Sagua La Grande, Villa Clara province, Cuba. Of these patients, 102 are male, the most frequent ages of the affected children are between 13 and 14 years, pain and poor sports performance were the predominant symptoms, $67.7 \%(\mathrm{n}=106)$ were in radiological stage II and $70.9 \%(\mathrm{n}=7)$ in pathological anatomical stage II, which is closely related, but not the clinical stages.

Keywords: epiphyseal injuries; apophyseal injuries; child athletes
\end{abstract}

\section{Introduction}

The injuries of the child athlete can appear at any time and part of the body and although they are generally not serious, they can cause psychological damage and pain, within these injuries are those of the muscle skeletal system, which are divided for study into accidents and injuries due to overuse [1-2], being one of the most frequent affections epiphyseal or apophyseal injuries, within the basic mechanisms in the production of sports injuries we find affections by contact, by impact, by dynamic overload and by overuse [3].

The use of medicine and its advances to achieve the reduction of injuries in immature athletes, is a contribution to the elevation of the quality of sports practice and an incentive to athletic performance, providing the athlete with a more fruitful and lasting life. Raising the knowledge not only of the child athlete, but that of their coaches and trainers as well as the health personnel who care for them, provides a better understanding and a greater possibility of recognizing the risks today, much more important if this happens in the School sport. [4]

Among the overuse injuries we can find those that damage the growth processes such as the calcaneal or anterior tibial process, where the most powerful tendons of the human body are inserted, they can also be found in other locations such as the patella or the tarsal scaphoid.

Generally, the constant activity of children in sports practice - also in daily life - can cause damage, whether direct trauma or repetitive micro-trauma, where the powerful tendons produce increased local tension in the area and structural tissue damage, which leading to vascularization disorders and therefore epiphyseal ischemic necrosis [5]. In 1968, Caffey was one of the first to propose calling diseases of the primary or secondary nuclei due to repetitive damage as chronic stress injuries [6].

The possibility of clinically understanding, radiologically corroborating an injury and demonstrating the phenomenon of epiphyso-apophyseal damage due to an overuse mechanism or chronic stress injury is the objective of this work, in which we present the results obtained by correlating clinical, radiological and pathologically the lesions in the child athlete.

\section{Material and Methods}

A longitudinal prospective study of 157 athletes who suffered chronic stress injuries was carried out, which were treated at the Mártires del 9 de Abril University Hospital in Sagua La Grande, Villa Clara province in Cuba, in a period of 20 years, between on January 1, 2000 and December 31,2020 . The following criteria were used for participation in this study: Inclusion criteria. - School-age children under 16 years of age, practicing organized sports activities. - Clinical and radiological diagnosis of chronic stress injury. - Attended in our orthopedic service, practicing a surgical technique known as Beck Perforations which required intervention and taking a sample for biopsy, analyzed in our Department of Pathology. Exclusion criteria. - Patients with a diagnosis of chronic 
stress injuries not operated on. - Patients over 16 years of age. - Children of preschool age. - Children not practicing sports. Exit criteria. - Patients who continued with rehabilitation treatment at another institution. Patients who abandoned the rehabilitation treatment. The surgical technique used consists of direct approach to the injury according to the damaged region, maintaining Campbell's postulates, taking a sample from the injured site and practicing between 8 and 10 perforations to the damaged epiphysis or apophysis, hemostasis, closure by planes and immobilization by a four week period.

The rehabilitation process began immediately with isometric exercises for the muscles involved. When immobilization was removed, strengthening exercises for said muscles and joint movements began, as well as ultrasound and heat. The samples were processed according to the Hematoxylin-Eosin technique. A parallel data collection model was made, where variables such as age, sex, type of sport practiced by the child, epiphysis or damaged apophysis, evolution time with the symptoms, radiological stage in which they were found, classifying it into the following stages: - Stage I: X-ray image is normal, - Stage II: Increased bone density and small fractures may appear. - Stage III: Multiple fractures and bone collapse. - Stage IV: Recovery of the normal radiological image. Glincher and Kensara's [7] anatomical pathological classification was also used for the lesions, as well as the results obtained. The data were processed by the SPSS.II version for Windows and were put into tables for evaluation.

\section{Results}

The children who most frequently present epiphyso-apophyseal injuries related to overuse are those who practice physical activities with balls $(41.9 \%)$ and those who perform physical activities of times and marks. Especially those who are between 13 and 14 years old.

Source: Database.

\begin{tabular}{|l|c|l|c|l|l|}
\hline \multirow{2}{*}{$\begin{array}{l}\text { Age Groups in } \\
\text { years }\end{array}$} & \multicolumn{2}{|l|}{ Type of Sport } & \\
\cline { 2 - 6 } & Ball Sport & $\begin{array}{l}\text { Combat } \\
\text { Sport }\end{array}$ & $\begin{array}{l}\text { Sports Time } \\
\text { Marks }\end{array}$ & Water Sports & Total \\
\hline Under 8 & 5 & 0 & 0 & 2 & $\mathbf{7}(\mathbf{4 , 5 \%})$ \\
\hline $\mathbf{8}-\mathbf{9}$ & 10 & 1 & 3 & 3 & $\mathbf{1 7}(\mathbf{1 0 , 8 \% )}$ \\
\hline $\mathbf{1 0}-\mathbf{1 2}$ & 25 & 10 & 15 & 5 & $\mathbf{5 5}(\mathbf{3 5 , 0 \%})$ \\
\hline $\mathbf{1 3}-\mathbf{1 4}$ & 19 & 17 & 18 & 9 & $\mathbf{6 3}(\mathbf{4 0 , 1 \% )}$ \\
\hline $\mathbf{1 5}-\mathbf{1 6}$ & 7 & 1 & 5 & 2 & $\mathbf{1 5}(\mathbf{9 , 6 \%})$ \\
\hline Total & $66(41,9 \%)$ & $29(19,4 \%)$ & $41(25,8 \%)$ & $21(12,9 \%)$ & $\mathbf{1 5 7}(\mathbf{1 0 0 \%})$ \\
\hline
\end{tabular}

\section{Table 1: Distribution of epiphyseal and / or apophyseal injuries in relation to the type of sport and age groups.}

Epiphyso-apophyseal conditions due to chronic stress in child athletes evolve with pain in $100 \%$ of children, this is a chronic pain generally of low intensity that is exacerbated with the practice of physical activities and training. Frequent swelling of the damaged area appears in our casuistry, we find that more than $90 \%$ present this type of clinical behavior and all the children also presented poor sports performance, regardless of the state in which they were. All of the above can be seen in table number 2 .

Source: Database.

\begin{tabular}{|l|l|l|l|l|}
\hline \multirow{2}{*}{ Clinical Data } & \multicolumn{2}{|c|}{ Children Athletes } & \multirow{2}{*}{ Total } & \multirow{2}{*}{$\%$} \\
\cline { 2 - 5 } & Male N \% & \multicolumn{2}{|l}{ Female } \\
n \% & & \\
\hline Pain & $102(64,5 \%)$ & $55(35,5)$ & 157 & 100 \\
\hline Low performance Sports & $102(64,5 \%)$ & $55(35,5)$ & 157 & 100 \\
\hline Swellings & $91(64,3 \%)$ & $50(35,7)$ & 141 & 90 \\
\hline $\begin{array}{l}\text { Functional Impotence and / or } \\
\text { Claudication }\end{array}$ & $81(64,0 \%)$ & $45(36,0 \%)$ & 126 & 80 \\
\hline Color, Blush & $40(53,3 \%)$ & $35(46,7 \%)$ & 75 & 48 \\
\hline Easy Tiredness & $20(40,0 \%)$ & $31(60,0 \%)$ & 51 & 32 \\
\hline
\end{tabular}

Table 2: Relationship between the number of children, sex and their fundamental clinical data when presenting apophyseal damage. 

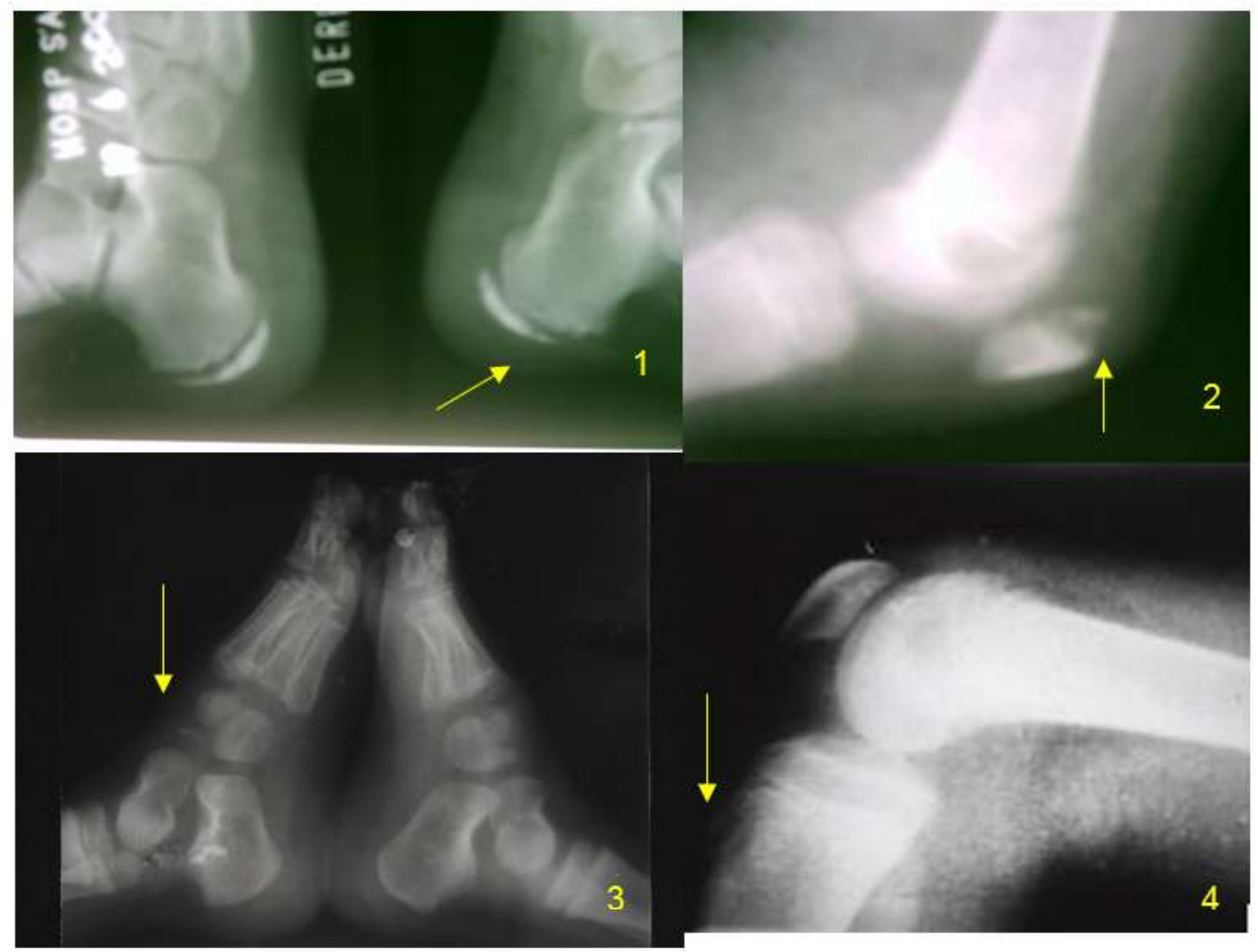

1. Osteochondritis of the calcaneal growth nucleus in a baseball player.

2. Osteochondritis of the upper pole of the patella in an athletic girl.

3. Osteochondritis of the scaphoid tarsal bone in a girl practicing gymnastics.

4. Osteochondritis of the tibial tubercle in a soccer player

Figure 1: Radiological images of epiphyseal diseases due to chronic stress in immature athletes, in their different evolutionary stages and different locations. (Photos by the author)

In Figure 1 we observe the radiological stages of the epiphyso-apophyseal lesions produced by overuse, lesions in different stages of evolution can be observed but in our study all evolved towards the chronic inflammatory response of the tissues, which was later corroborated with radiographs and analysis pathological anatomy of samples taken during surgical interventions. The pathological anatomical analysis of the conditions is difficult to perform in these cases, since they are generally children who do not have a serious disease and a large percentage of them heal with rest and medical treatment, for this reason only 11 cases were operated on.

Anatomically pathologically, they present in several stages (Figure 2) initially chronic stress and epiphyseal or apophyseal tension produces damage to the microcirculation with tears of the vascular system and the deprivation of blood supply to the epiphysis, which translates into changes in the Tissues with swelling and cell death secondarily appear features of the necrotizing process of the epiphysis, it is very rare for the entire epiphyseal nucleus to be damaged, later a stage of changes begins where repair begins in the epiphysis or apophysis, when observing this stage we can see signs old hemorrhage, cystic degeneration and replacement fibrosis, granulation areas may appear from mesenchymal cells, neo-formed capillaries and demineralization of some areas, radiologically this stage is observed as fragmentation of the epiphysis, later the dead bone - third stage - is generally replaced by granulations from the metaphysis, in our study we accelerated this neo-formation and migration of neo-formed vessels with Beck's perforations in children who required surgical intervention. These perforations accelerate the revascularization process, due to the invasion of neo-formed vessels that they produce. 


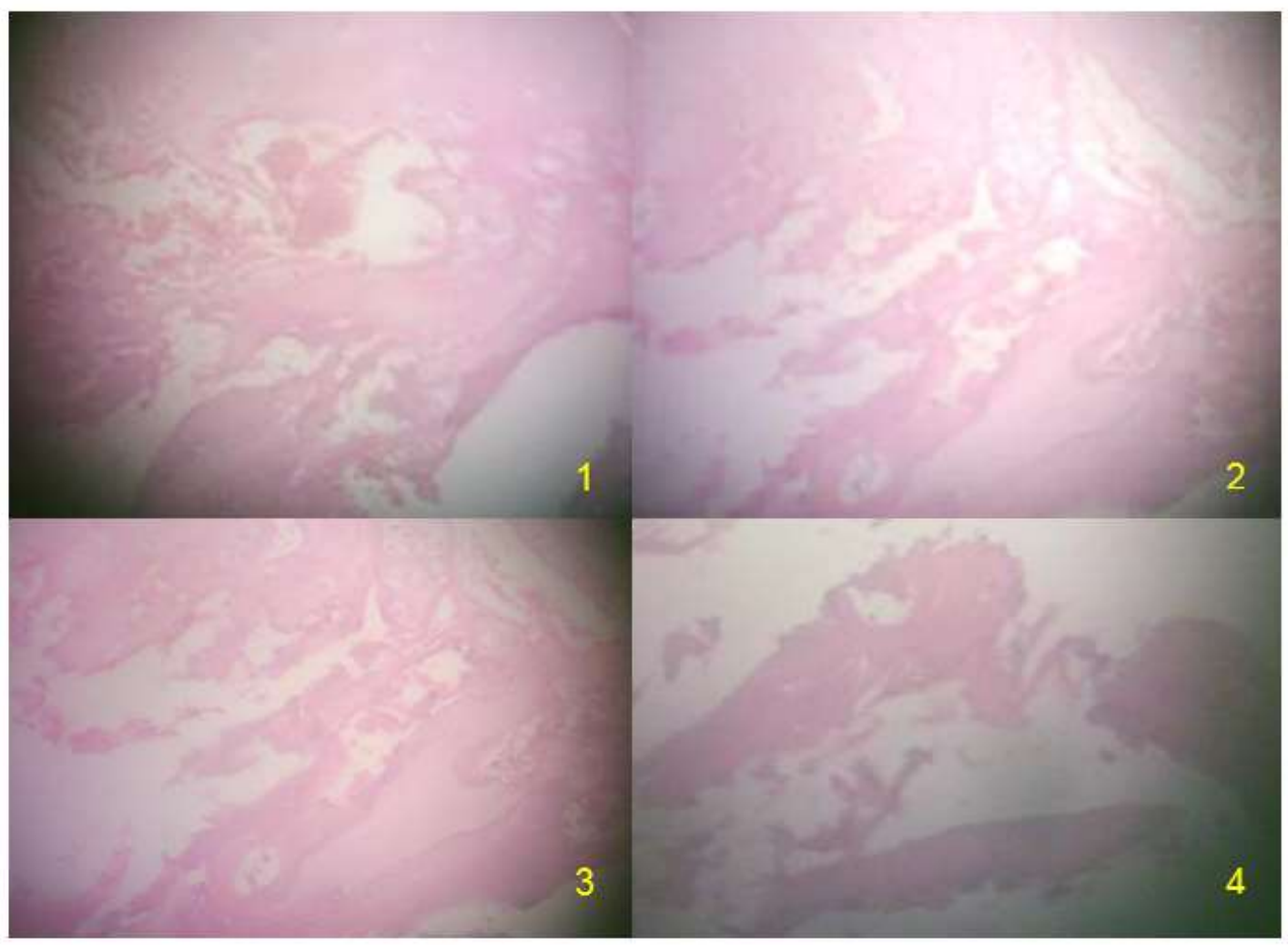

1. Phase 1. Necrotic changes in hematopoietic, bone and adipose cells.

2. Phase 2. Necrotic bone contiguous to healthy bone.

3. Phase 3. Repair and remodeling of the interface.

4. Phase 4. Collapse of the bone.

Figure 2: Microscopic images of chronic stress epiphyseal injuries in immature athletes, note the different stages of evolution. (Photos by the author)

The anterior tuberosity of the tibia and the calcaneal epiphysis were the most injured areas, very vulnerable places due to the thick tendons that are inserted in them, in addition, they are the termination of powerful muscles such as the Quadriceps and the Gastrocnemius, which cause high tensions during its function in the practice of physical exercises. It is striking as the symptoms they evolve for more than six weeks before diagnosis and even after diagnosis and treatment.

\begin{tabular}{|c|c|c|c|c|c|c|}
\hline \multirow[t]{2}{*}{$\begin{array}{l}\text { Epiphysis or apophysis } \\
\text { damaged }\end{array}$} & \multicolumn{3}{|c|}{$\begin{array}{l}\text { Evolution with pain } \\
\text { before diagnosis }\end{array}$} & \multicolumn{3}{|c|}{$\begin{array}{l}\text { Evolution with pain } \\
\text { after diagnosis and treatment }\end{array}$} \\
\hline & $\begin{array}{l}\text { Less than } 3 \\
\text { weeks }\end{array}$ & $\begin{array}{l}\text { Between } 3 \text { and } \\
6 \text { weeks }\end{array}$ & $\begin{array}{l}\text { More than } 6 \\
\text { weeks }\end{array}$ & $\begin{array}{l}\text { Less than } 3 \\
\text { weeks }\end{array}$ & $\begin{array}{l}\text { Between } 3 \text { and } \\
6 \text { weeks }\end{array}$ & $\begin{array}{l}\text { More than } 6 \\
\text { weeks }\end{array}$ \\
\hline Tibial anterior tuberosity & 10 & 15 & 61 & 7 & 35 & 47 \\
\hline Calcaneal tuberosity & 3 & 10 & 38 & 2 & 24 & 31 \\
\hline $\begin{array}{l}\text { Upper or lower pole of } \\
\text { the ball joint }\end{array}$ & 1 & 2 & 4 & 1 & 1 & 1 \\
\hline Scaphoidtarsal & - & 1 & 1 & - & - & 1 \\
\hline Proximal humerus & 1 & 1 & 3 & - & 1 & 2 \\
\hline Elbow Area & - & 1 & 3 & - & 1 & 2 \\
\hline Semilunar & - & - & 1 & - & - & 1 \\
\hline Total & $15(9,7 \%)$ & $30(19,4 \%)$ & $111(70,9 \%)$ & $10(6,5 \%)$ & $62(39,7 \%)$ & $85(53,8 \%)$ \\
\hline
\end{tabular}

Source: Database.

Table 3: Relationship between the damaged epiphysis and the period of evolution of the injured children, before and after diagnosis.

In Table 4 we describe the radiological and anatomical pathological correlation of the epiphyseal injuries due to chronic stress in the child athletes who attended our consultation, most of the injuries are in stage II
( $\mathrm{n}=7$ ), only 11 children were operated on , most were treated conservatively. 


\begin{tabular}{|c|c|c|c|c|}
\hline \multirow{2}{*}{ Stadium } & \multicolumn{2}{|l|}{ Radiologic } & \multicolumn{2}{l|}{ Anatomic-pathological } \\
\cline { 2 - 5 } & Number of children & $\%$ & Number of children & $\%$ \\
\hline I & 20 & 12,9 & 1 & 9,1 \\
\hline II & 106 & 67,7 & 7 & 63,6 \\
\hline III & 21 & 13,1 & 2 & 9,1 \\
\hline IV & 10 & 6,3 & 1 & \\
\hline
\end{tabular}

\section{Likelihood ratio test}

Chi-square $=0.4064 \mathrm{gl}=3 \mathrm{p}$-value $=0.9389$

$\neg$ Measures of association for nominal variables

Contingency coefficient $=0.0501$ Cramer's V coefficient $=0.0501$

Tau of Goodman and Kruskal. Rows $/$ columns $=0.0025$ Columns $/$ rows $=0.0007$

Source: Database.

Table 4: Radiological and anatomic pathological correlation of chronic stress injuries in the child athletes in our study.

\section{Discussion}

Knowledge of the pathophysiology, clinical symptoms and radiological findings of traction bone lesions will allow a correct diagnosis to be made and can avoid, on the one hand, that the patient is exposed to excessive complementary tests or unnecessary invasive procedures, and on the other that the healthcare professional makes diagnostic errors. [8]

Epiphyso-apophysitis is a common and clinically important disorder that occurs in humans. This disease is defined as a focal endochondral ossification disorder and is considered to have a multifactorial etiology. The most common etiologic factors are heredity, rapid growth, anatomical conformation, trauma, and dietary imbalances; However, only inheritance and anatomical conformation have been demonstrated by the scientific literature. The way in which the disease starts has been discussed. Although the formation of a brittle cartilage, the failure of chondrocyte differentiation, subchondral bone necrosis, and failure of the blood supply to the growth plate have been invoked as the initial step in pathogenesis, recently the literature has provided important evidence regarding failure of growth plate blood supply as the most likely cause. Osteochondritis is the term used to describe a wide variety of different lesions to the growth plate and growth plate in the human body. [9]

In our casuistry, the highest percentage effectively corresponds to children who play sports with balls, this is found in relation to children who play soccer and throw balls, $[10,11,12]$ also repeated injuries to the elbow of pitchers. Athletic implements, they agree that injuries appear after prolonged, repetitive work and fatigue. [13] Valasek AE et al. [14] report that children are the most affected. Ishida recommends the practice for young children who perform sports activities with balls use lighter implements, depending on their age. [15]

Returning to competitions safely after injury is a process that must involve the injured athlete as a whole, where members of the rehabilitation team must work together to study the biological, neuromechanical, metabolic and psychosociological aspects of rehabilitation, with special emphasis on the final phases of functional recovery, which must be carried out in the field. In general, the child athlete is able to return to full activity faster than the adult athlete, and if the injury has already occurred, it is necessary to avoid its aggravation and provide a treatment that leads to healing, with a reintegration to the sport, nuanced and controlled by the biological time of restitution and integrity. This happens when the acute signs and symptoms have been eliminated, the child can use all his joints to the maximum and he has sufficient strength and proprioception to carry out the tasks, also the movement mechanisms are normal.[16, 17]
Regardless of our study, there are no variations with the clinic, since all the children invariably the stage in which they were found presented a similar clinical picture characterized by pain and decreased sports performance, however in the radiological and anatomic pathological stages there is a significant correlation, the stage in which we most frequently find affected children was stage II or revascularization or repair phase, where necrotic bone is invaded by blood vessels and osteogenic tissue, with fibrosis, these go from healthy bone to necrosis. According to this process, a replacement of the old bone appears that is gradually reabsorbed and replaced by new tissue, this stage can last from months to years, depending on the evolution towards a chronic inflammatory response.

Another less numerous group was in stage III or remodeling phase, where osteoblasts appear, initiating cells of the osteogenesis process, at this stage these cells appear along the reactive interface between the viable zone and the osteonecrosis. If this phase were normal and the stresses on the epiphysis decreased, then the osteoblasts should form immature reticular bone that would be progressively reabsorbed by the osteoclasts, giving rise to lamellar bone capable of replacing the necrotic area. On many occasions, this normal process is altered and the precursor cells are transformed into osteoclasts and fibroblasts instead of osteoblasts, therefore depending on the predominance of one or the other cells, the filling of the area will be, if osteoclasts predominate, reabsorption will occur, if fibroblasts predominate, the filling zone will be predominant in fibrous tissue. The classic description of the histological changes that take place in the bone when there is avascular necrosis is based on the studies carried out in 1979 by Glincher and Kenzara [7] which caused an ischemic reaction and should be considered as a complex and continuous process of necrosis , revascularization and repair, trabecular bone resorption weakness and stress fractures.

In phase IV we only found a girl athlete with damage to the lunate which collapsed when she lost her elastic capacities to absorb compression and shear stresses resulting in fatigue fractures. She was a field tennis player.

Epiphyso-apophysitis are common causes of bone pain but they have discrepant etiologies and require systematic investigation. Apophysitis results from a traction injury to the cartilage and the bone insertion of tendons in children and adolescents. $[18,19]$ It is most often an overuse injury in children who grow up to have inflexible musculoskeletal units. Although they occur more frequently in the lower extremities, they also appear in the upper limb.[20] Radiography can be helpful in positive and differential diagnosis. [21, 22] 
Osteochondritis or epiphysitis and apophysitis are terms that are often confused; however, these two conditions should be considered separately because they have different etiologies and their therapeutic management is also different. [23] Conduct should always begin with injury prevention with better sports training planning. [24, 25]

\section{Conclusions}

Pain and decreased sports performance in child athletes are the frequent clinical manifestations in epiphyseal-apophyseal lesions, in children between 13 and 14 years of age they are the most frequently affected in those who play sports with balls. The most damaged areas or anatomical regions are those that are related to the most powerful tendons and muscles of the body, such as the knee on the front side and the calcaneus. There is a close radiological and pathological correlation between epiphyseal apophyseal lesions due to overuse in children.

\section{References}

1. Martínez Estupiñán LM, Martínez Aparicio L, Martínez Aparicio L. Lesiones deportivas en el niño atleta. Valoraciones sobre antecedentes y prevención (I). Revista Cubana de Medicina del Deporte y la Cultura Física. 2019;14(1):e25

2. Patel DR, Yamasaki A, Brown K. Epidemiology of sports-related musculoskeletal injuries in young athletes in United States. Transl Pediatr. 2017;6(3):160-166.

3. Launay F. Sports-related overuse injuries in children. Orthopedics \& Traumatology: Surgery \& Research. 2015;10(1):139-147.

4. Martínez Estupiñán L. Lesiones deportivas en niños atletas. Estudio de veinte años. Medisur [revista en Internet] 2017 [acceso 28 de diciembre 2017]; 15(6): [aprox. 6 p.].

5. Aegerter E, Kirkpatrick JA. Enfermedades ortopédicas, fisiología, patología, radiología. Ed Rev. 1978.

6. Caffey J. Lesiones por estrés crónico. Am J. Roentgenol. 1968;103:620-41.

7. Glincher MF, Kenzara JE. The biopsy of osteonecrosis of the human femoral head and its clinical implications: Part 1. Clin Orthop 1979;138:284-304.

8. Segura D, Mínguez MF, Pino L. Lesiones óseas por tracción: a propósito de un caso. Revista Española de Cirugía Osteoarticular. 2016;268(51):180-188.

9. Ytrehus B, Carlson CS, Ekman S. Etiology and Pathogenesis of Osteochondrosis. Vet Pathol. 2007;44:429-448.
10. Duarte ML, et al. Bilateral Severs disease-An uncommon finding. J Pediatr Neonatal Care. 2018;8(2):110-111.

11. Fischer AN. Sinding-Larsen-Johansson Syndrome. En Common Pediatric Knee Injuries. Springer, Cham, 2021. p. 63-68.

12. Brown Th, Moran M. Pediatric sports-related injuries. Clinical Pediatrics. 2019;58(2):199-212.

13. Della Villa F, et al. Apophysitis. En Injuries and Health Problems in Football. Springer, Berlin, Heidelberg, 2017. p. 473-479.

14. Valasek AE, et al. Age and Sex Differences in Overuse Injuries Presenting to Pediatric Sports Medicine Clinics. Clinical pediatrics. 2019;58(7):770-777.

15. Ishida $\mathrm{K}$, Murata $\mathrm{M}$, Hirano $\mathrm{Y}$, Shoulder and elbow kinematics in throwing of young baseboll players. Sports Biomech 2006; 5 (2): 183- 196.

16. Tunay VB. Return to Sport Activities. En: Doral M. Sports Injuries: Prevention. Diagnosis, Treatment and Rehabilitation. Berlin Heidelberg: Springer-Verlag; 2012. p. 1145-1155.

17. De Pablo Márquez, $\mathrm{B}$, et al. Patología traumatológica pediátrica. FMC-Formación Médica Continuada en Atención Primaria. 2020;27(6):1-18.

18. Gicquel P. Osteocondrosis u osteodistrofias de crecimiento del tobillo y del pie. EMC-Podología. 2017;19(2):1-10.

19. Bronfen C, Desdoitis A. Cojeras infantiles. EMC-Podología. 2018;20(1):1-13.

20. Larraín C, Salinas M. Lesiones deportivas por sobreuso en niños y adolescentes. Revista Médica Clínica Las Condes. 2021;32(3):329-335.

21. De Castro JC. US in Children with Sports Injuries. En Pediatric Musculoskeletal Ultrasonography. Springer, Cham, 2020. p. 339348.

22. Weidekamm C. Tendon and muscle imaging in sports injuries. Ultrasound in Medicine and Biology. 2019;45:S46.

23. Achar S, Yamanaka J. Apophysitis and Osteochondrosis: Common Causes of Pain in Growing Bones. Am Fam Physician. 2019;99(10):610-618.

24. Egger AC, Oberle LM, Saluan P. The Effects of Endurance Sports on Children and Youth. Sports Medicine and Arthroscopy Review, 2019;27(1):35-39.

25. Martínez Estupiñán LM, Santana Lugones JL, Álvarez Cambras RJ. Lesiones deportivas en el niño atleta. Sistema de prevención (III). Revista Cubana de Medicina del Deporte y la Cultura Física. 2019;14(3):e39

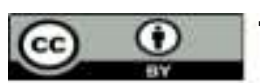

This work is licensed under Creative Commons Attribution 4.0 License
To Submit Your Article Click Here: $\quad$ Submit Manuscript

DOI: $10.31579 / 2694-0248 / 016$
Ready to submit your research? Choose Auctores and benefit from:

$>$ fast, convenient online submission

$>$ rigorous peer review by experienced research in your field

$>$ rapid publication on acceptance

$>$ authors retain copyrights

$>$ unique DOI for all articles

$>$ immediate, unrestricted online access

At Auctores, research is always in progress.

Learn more https://auctoresonline.org/journals/clinical-orthopaedics-andtrauma-care 